\title{
Middle East respiratory syndrome coronavirus: current situation and travel-associated concerns
}

\author{
Jaffar A. Al-Tawfiq ${ }^{1,2}$, Ali S. Omrani ${ }^{3}$, Ziad A. Memish $(\bowtie)^{4,5}$ \\ ${ }^{1}$ Johns Hopkins Aramco Healthcare, Dhahran 31311, Kingdom of Saudi Arabia; ${ }^{2}$ Indiana University School of Medicine, Indianapolis, IN \\ 46202-3082, USA; ${ }^{3}$ Department of Medicine, Section of Infectious Diseases, King Faisal Specialist Hospital and Research Centre, Riyadh \\ 11211, Kingdom of Saudi Arabia; ${ }^{4}$ Ministry of Health, Riyadh 11514, Kingdom of Saudi Arabia; ${ }^{5}$ College of Medicine, Alfaisal University, \\ Riyadh 11533, Kingdom of Saudi Arabia
}

(C) Higher Education Press and Springer-Verlag Berlin Heidelberg 2016

\begin{abstract}
The emergence of Middle East respiratory syndrome coronavirus (MERS-CoV) in 2012 brought back memories of the occurrence of severe acute respiratory syndrome coronavirus (SARS-CoV) in 2002. More than 1500 MERS-CoV cases were recorded in 42 months with a case fatality rate (CFR) of $40 \%$. Meanwhile, 8000 cases of SARS-CoV were confirmed in six months with a CFR of $10 \%$. The clinical presentation of MERS-CoV ranges from mild and non-specific presentation to progressive and severe pneumonia. No predictive signs or symptoms exist to differentiate MERS-CoV from community-acquired pneumonia in hospitalized patients. An apparent heterogeneity was observed in transmission. Most MERS-CoV cases were secondary to large outbreaks in healthcare settings. These cases were secondary to community-acquired cases, which may also cause family outbreaks. Travel-associated MERS infection remains low. However, the virus exhibited a clear tendency to cause large outbreaks outside the Arabian Peninsula as exemplified by the outbreak in the Republic of Korea. In this review, we summarize the current knowledge about MERS-CoV and highlight travel-related issues.
\end{abstract}

Keywords coronavirus; MERS; Middle East respiratory syndrome

\section{Introduction}

The emergence of Middle East respiratory syndrome coronavirus (MERS-CoV) in 2012 brought back memories of the occurrence of severe acute respiratory syndrome coronavirus (SARS-CoV) in 2002 [1,2]. As of March 17, 2016, 1715 MERS-CoV cases were confirmed with a case fatality rate (CFR) of approximately $40 \%$, whereas 8000 SARS-CoV cases were recorded in six months with a $10 \%$ CFR [1-3]. An upsurge in the number of cases was observed in March-May 2014 because of the outbreak in large healthcare facilities in Jeddah, Kingdom of Saudi Arabia (KSA) [4,5]. More recently, a larger outbreak occurred in Riyadh, KSA and in multiple hospitals in South Korea [6-9].

Wolfe et al. [10] described the five stages of pathogen evolution that lead to diseases confined to humans. In stage 1 , the pathogen is confined to an animal host. Humans

Received September 30, 2015; accepted March 21, 2016

Correspondence: zmemish@yahoo.com become infected by animals only in stage 2 . Stage 3 is limited human-to-human transmission. In stage 4, long outbreaks with numerous cycles of human-to-human transmission occur. In stage 5, the pathogen exclusively infects humans [10]. MERS-CoV has not yet reached stage 5. The interest and concern of the public and the health community in emerging infectious diseases stem from the ability of the emerging pathogens to cause pandemics with high fatality rates and the associated economic effects on affected countries. For example, SARS-CoV caused \$3050 billions of economic losses in Mainland and Hong Kong of China, Singapore, and Canada, and the pandemic influenza H1N1 in 2009 resulted in $\$ 45-55$ billion losses worldwide [11]. In this review, we focus on the important aspects of the recently emerged MERS-CoV, its effects on humans, and the transmission patterns of the disease based on available scientific data.

\section{Timeline of MERS-CoV epidemic}

The first reported MERS-CoV case from KSA was a 60- 
year-old male from Bisha $[12,13]$. The patient was hospitalized with community-acquired pneumonia; the disease rapidly progressed, resulting in acute renal failure, respiratory failure, and death [13]. A summary of the major events in the development of the MERS-CoV epidemic is shown in Fig.1.

\section{Contact and environmental investigations}

Since the first case of MERS-CoV, a detailed investigation was conducted to determine the environmental and animal source of the virus. Extensive contact investigation was carried out on the first case that originated from Bisha but was eventually hospitalized in a private hospital in Jeddah $[12,14]$. The contact investigation started in the patient's hometown of Bisha in southern KSA. The investigation included his immediate household contacts (3 wives, 10 sons, 11 daughters, 12 grandchildren, and 1 house maid), as well as the community and healthcare facility in Bisha, which included 2 shepherds who took care of his five camels and 14 healthcare workers (HCWs) (11 nurses and three physicians) [14]. In total, 53 contacts in Bisha were screened and all of them tested negative for MERS-CoV by polymerase chain reaction (PCR) [14]. An extensive investigation of the 48 out of $56 \mathrm{HCW}$ who had significant contact with the same patient during his 10-day stay in the private hospital in Jeddah tested negative [15]. During the October 2012 investigation on the source of the virus, a team representing three agencies, namely, Saudi Ministry of Health, Center for Infection and Immunity of Columbia University, and EcoHealth Alliance, interviewed the family of the index case-patient from Bisha. The team also collected samples from bats within $12 \mathrm{~km}$ from his home, as well as an abandoned date palm orchard, the area within $1 \mathrm{~km}$ from his place of employment, a hardware store that fronted his garden, and a date palm orchard.
Although none of his family members nor employees recalled seeing bats, the investigating team observed the roosting bats and guano in abandoned wells and ruins within $12 \mathrm{~km}$ of his home and insectivorous bats at dusk in the garden behind his store. A sample from a Taphozous perforatus bat (Egyptian tomb bat) captured in Bisha showed $100 \%$ identity to the human $\beta-\mathrm{CoV} 2 \mathrm{c}$ EMC/2012 cloned from the index case-patient [16]. The largest data set on the contact investigation revealed that the percentage of positive cases was $2.5 \%, 1.12 \%, 3.03 \%$, and $2.09 \%$ among hospital patients, HCW contacts, family and contacts, and overall [17].

With the expansion of testing to identify the full disease spectrum and the inclusion by the World Health Organization (WHO) of the positive cases by serology in July 2014 [18], the CFR gradually decreased from $60 \%$ to $40 \%$ as more asymptomatic and mildly symptomatic cases were included [19]. A nationwide serosurvey for MERS-CoV conducted in the KSA between December 2012 and December 2013 suggested that around 45000 infected individuals were not aware of their infection, which confirmed an extremely high incidence of asymptomatic to mildly symptomatic disease [20].

\section{Family clusters}

A good example of a family cluster of MERS-CoV infections was published in the New England Journal of Medicine [21]. Once the second case in that cluster was identified, an epidemiologic investigation identified the index case who was the father of the second case who was admitted earlier with congestive heart failure and community-acquired pneumonia. Subsequently, the third and fourth cases where recognized [21]. In that cluster, 28 persons lived in the same extended household, including nine children $(<14$ years of age) [21]. Aside from the

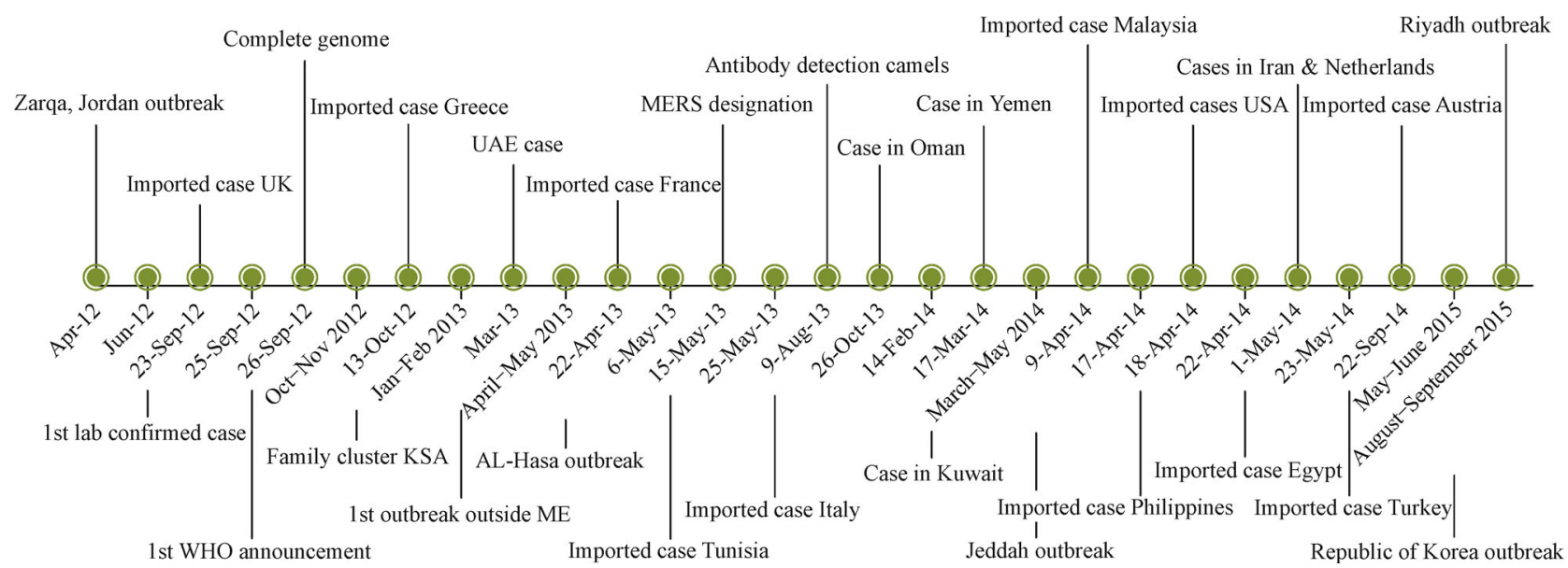

Fig. 1 A summary of the major events in the timeline of MERS-CoV epidemic. 
four patients, no other family members had major respiratory symptoms and none of the $124 \mathrm{HCWs}$ who managed the index case before the MERS-CoV diagnosis exhibited symptoms [21]. A second family cluster was also described by Omrani et al. [22]. Three patients lived in one large house in urban Riyadh. None of the other family contacts had positive PCR tests. Community outbreak was also described [23]. The first patient infected his cousin, and each of the patients infected their parents. Genome analysis showed multiple introduction of the virus and determined three distinct genotypes, which confirm very low patient-to-patient transmission [23-26].

\section{Healthcare-associated outbreaks}

A number of healthcare-associated outbreaks were reported previously $[14,19,27,28]$. A cluster of acute respiratory illnesses was reported in the intensive care unit (ICU) in Zarqa, Jordan in April 2012 [29]. Thirteen $\mathrm{HCW}$ cases were detected (intensivists and ICU nurses) with two mortalities. An initial investigation revealed no etiology. After the announcement of the first case of MERS-CoV in September 2012 in KSA, samples from these patients were retested for MERS-CoV and confirmed to be positive in two patients by PCR and eight contacts by serology $[29,30]$. Thus, this case demonstrated MERS$\mathrm{CoV}$ as a healthcare outbreak. The second large outbreak occurred in Al-Hasa, KSA in April 2013 [26]. A total of 23 confirmed cases and 11 probable cases were recorded. A detailed transmission map was drawn based on the best available epidemiological data linking these patients epidemiologically [26]. Subsequent genotyping showed multiple introduction of the virus leading to the outbreak rather than a single introduction [25]. Four of the cases did not match the transmission, which indicates that the disease was not likely transmitted between the cases but had a different genome, thus indicating multiple community introductions [25]. The outbreak was controlled with simple infection control measures in three weeks. MERS$\mathrm{CoV}$ was shown to have minor clades, and the most recent common ancestor of MERS-CoV was introduced into humans at the end of 2010 [31]. MERS-CoV is closely related to Pipistrellus bat CoV HKU5 (Pi-BatCoV HKU5) in bats from Hong Kong and these bats diverged from a common ancestor several centuries ago [32].

In 2014, one of the largest healthcare-associated outbreaks of MERS-CoV infection took place between February 17 and April 26 in Jeddah, KSA [4]. A total of 128 MERS-CoV patients were treated in 14 hospitals $[4,5]$. The number of cases in each hospital varied from 2 to 45 cases $[4,5]$. In all the cases, $33 \%$ were primary cases and $60 \%$ (including $39 \mathrm{HCW}$ ) were healthcare-associated infections [33]. The rapid increase in the cases was attributed to more sensitive case detection, active case determination, and contact tracing with changes in testing algorithms [4]. A breakdown in infection control measures was observed with no change in the virus [4]. A near full genome sequence of the three viruses from the early phase of the Jeddah outbreak showed a highly similar virus with no genome insertions or deletions [4]. The genetic marker influencing transmissibility was $100 \%$ identical to known MERS-CoV genomes [4].

In 2015, the largest outbreak outside the Middle East took place in South Korea [6]. The index case was a 68year-old male who visited Bahrain, KSA, United Arab Emirates, and Qatar [6]. He developed symptoms on May 11, 2015 and visited multiple hospitals in South Korea [6]. He caused an outbreak involving five health care facilities and 63 cases [7], with 34 cases in hospital B, 18 cases in hospital D, 5 cases in hospital E, and three cases in hospital F [7]. As of June 19, 2015 the outbreak in the Republic of Korea involved 72 health care facilities, and six facilities exhibited nosocomial transmission [8]. The total number of cases as of July 21, 2015 was 186 cases with 36 deaths $[34,35]$.

\section{Seasonality}

Based on epidemiological data monitoring over the last three years, the potential seasonality of MERS-CoV from March to May and from September to November was observed. In April and May 2014, the number of cases increased [4]. One of the reasons for this increase in the number of cases is the parallel surge in MERS-CoV tests in Jeddah [4]. This increase is also facilitated by an intensified intra-hospital and inter-hospital transmission of MERS$\mathrm{CoV}$ with no change in the virus genetic composition or ability to cause disease $[4,27]$. Thus, seasonality is difficult to establish because sporadic cases were documented with amplifications mainly occurring during nosocomial outbreaks.

\section{Clinical presentation}

Available data to date show that MERS-CoV behaves differently in various conditions and in different population of patients. Isolated sporadic cases, small family clusters, as well as large healthcare-acquired infections and clusters, were recorded. Most cases present with respiratory symptoms and about one-third had gastrointestinal symptoms (Table 1) [26,36-40]. Early symptoms are mild and non-specific, which last several days prior to progressing to severe pneumonia. No predictive signs or symptoms exist to differentiate MERS-CoV from community-acquired pneumonia in hospitalized patients [38]. An apparent heterogeneity in transmission was observed. The severity of the disease is usually seen in primary or index 
Table 1 Summary of the number of cases of MERS-CoV with designated symptoms and signs from four different studies and the total percentage of patients with any given symptom or sign

\begin{tabular}{|c|c|c|c|c|c|c|}
\hline & Assiri et al. [26] & Saad et al. [36] & Al-Tawfiq et al. [37] & Arabi et al. [38] & Assiri et al. [39] & Shalhoub et al. [40] \\
\hline Total & 23 & 70 & 17 & 12 & 47 & 24 \\
\hline Male & 17 & 46 & 11 & 8 & 36 & 14 \\
\hline Diabetes mellitus & 17 & - & 13 & 8 & 32 & 15 \\
\hline Cardiac disease & 9 & - & 11 & 7 & 13 & 0 \\
\hline Renal failure & 12 & - & - & 5 & 23 & 10 \\
\hline Hemodialysis & - & - & 5 & 1 & - & 6 \\
\hline Malignancy & - & - & 1 & 1 & 1 & 0 \\
\hline Hypertension & - & - & 6 & 6 & 16 & 18 \\
\hline Fever & 20 & 43 & 10 & 8 & 46 & 19 \\
\hline Dyspnea & 11 & 42 & 1 & 11 & 34 & 20 \\
\hline Chest pain & - & - & 12 & 10 & 7 & 0 \\
\hline Cough & 20 & 38 & 1 & 1 & 39 & 21 \\
\hline Hemoptysis & - & 6 & 1 & 1 & 8 & - \\
\hline Sore throat & - & - & 1 & 2 & 10 & - \\
\hline Headache & - & 9 & 1 & 3 & 6 & - \\
\hline Myalgia & - & 14 & 1 & - & 15 & - \\
\hline Vomiting & 4 & 21 & 1 & - & 10 & 4 \\
\hline Diarrhea & 5 & 21 & 1 & 2 & 12 & 3 \\
\hline Weakness & - & 21 & 1 & 2 & 12 & - \\
\hline Abdominal pain & - & 17 & - & - & 8 & 2 \\
\hline Rhinorrhea & - & - & 6 & 1 & 2 & - \\
\hline Lymphopenia & - & 36 & - & 9 & 16 & - \\
\hline Thrombocytopenia & 4 & - & - & 2 & 17 & - \\
\hline
\end{tabular}

cases, immune-compromised individuals, and people with underlying comorbidities. Mild or asymptomatic disease usually occurs in secondary cases and was initially thought to infect the young and previously healthy individuals. However, mortalities and severe cases were observed among primary cases and young individuals [10]. However, person-to-person transmission as a definite route of transmission is still unclear. The median incubation period was 5.2 days (95\% CI, 1.9 to 14.7$)$, and the serial interval was 7.6 days (95\% CI, 2.5 to 23.1) [26]. CFR is directly related to the number of comorbidities, the increasing detection of asymptomatic to mildly symptomatic cases over the last three years [39]. However, mortalities were reported among healthy individuals. The median time to hospitalization was 4 days, ICU admission was 5 days, mechanical ventilation was 7 days, and death was 11.5 days $[26,41]$.

\section{Laboratory samples}

MERS-CoV PCR was standardized, and it works extremely well with lower respiratory samples in experienced laboratories. Confirmatory testing in national or regional reference laboratories with experience and load of samples will avoid reporting false positive cases. On November 5, 2013, a Spanish case from Hajj was initially tested positive for MERS-CoV but was eventually sent to an outside reference laboratory for confirmatory testing; all tests were negative [42]. If MERS-CoV infection is suspected and initial testing is negative, repeat testing is recommended and lower respiratory tract samples would yield higher positivity [43]. In July 2014, a key change in MERS-CoV case definition is the inclusion of a confirmed case based on serology [44]. Serologic MERS-CoV confirmation requires sero-conversion in two samples taken at least 14 days apart by a screening (ELISA, IFA) and a neutralization assay [44].

\section{Travel-related MERS-CoV}

Since the emergence of MERS-CoV and till October 2015, 1715 cases were reported in different countries [45]. The cases included 1403 cases in the Middle East, 15 cases in Europe, 191 in Asia, and 7cases in other countries [45]. The WHO International Health Regulations (IHR) Emergency Committee convened a MERS-CoV emergency committee meeting on multiple occasions; after extensive deliberations and reviews of available data, the diseases 
did not fulfill the IHR requirements to be defined as a public health emergency of international concern (PHEIC) and mainly sustained human-to-human transmission [46,47] (Fig.2).

Using a mathematical model, the risk of MERS-CoV was estimated to be one to seven cases per Hajj and three to ten Umrah pilgrims per year [48]. In another model, 6.2 pilgrims were estimated to develop MERS-CoV symptoms during the Hajj, and 4.0 foreign pilgrims will be infected but return home before developing symptoms [49]. Travelrelated MERS-CoV occurred infrequently among pilgrims performing the Umrah [50]. However, millions of pilgrims who performed the annual Hajj did not exhibit MERSCoV symptoms [51]. A cross sectional study of 839 African Hajj pilgrims returning to Ghana, West Africa in 2013 showed that none of the pilgrims was positive for MERS-CoV [52]. A cohort of French pilgrims exhibited no MERS-CoV infection [53]. No MERS-CoV was detected by PCR among 5235 adult pilgrims from 22 countries [54]. Although the risk of travel-associated MERS-CoV remains low, the potential for healthcareassociated infections in relation with an imported MERS$\mathrm{CoV}$ is a real concern. This event took place in the Republic of Korea [6-9]. Thus, all HCWs should be vigilant to the importation of MERS from returning travelers and healthcare organizations should implement a strategy to screen, isolate, and diagnose these patients.

\section{Seroprevalence of MERS-CoV}

Serologic testing allowed the detection of eight of the 124 contacts in the Jordan cluster [30]. The positive results were confirmed in six of nine outbreak members, one in 26 household contacts, and one in 89 HCWs [30]. Interest- ingly, one $\mathrm{HCW}$ who tested positive did not recall having respiratory symptoms at the time of the outbreak [30]. A few published serology studies did not present any background on MERS-CoV. In one study, eight out of 356 abattoir workers and blood donors had weak positive tests by IFA, and none of these individuals tested positive by NT in Jeddah and Makkah in 2012 [55]. In a second study, none of 268 children with respiratory tract disease and blood donors showed neutralizing antibodies in Dammam, KSA in 2010-2012 [55].

An initial study of 268 samples that were tested for MERS-CoV antibodies in the Eastern Saudi Arabia revealed no positive samples [55]. A serologic evaluation of 280 household contacts of 26 index patients showed 12 probable cases of secondary transmission $(4 \%$; $95 \%$ confidence interval, two to seven) [56]. A large-scale study of more than 10000 samples demonstrated that the overall seroprevalence in KSA was $0.15 \%$ and detected an increase of 17- and 26-fold of antibody detection rate among camel shepherds and abattoir workers compared to that in the general population [20].

\section{MERS-CoV genome sequences}

The full genome sequences from MERS patients with known dates and locations can help answer these questions: How fast does the virus change? When did the virus begin circulating in its current form? Is the virus adapting to humans? Can the geographical patterns help locate an animal source? What are the transmission patterns? A previous study showed that sequence success is as function of viral load, which is inversely proportional to the threshold cycle value $(\mathrm{Ct})$ in real-time PCR assays [25]. Ct values below 33 are associated with good

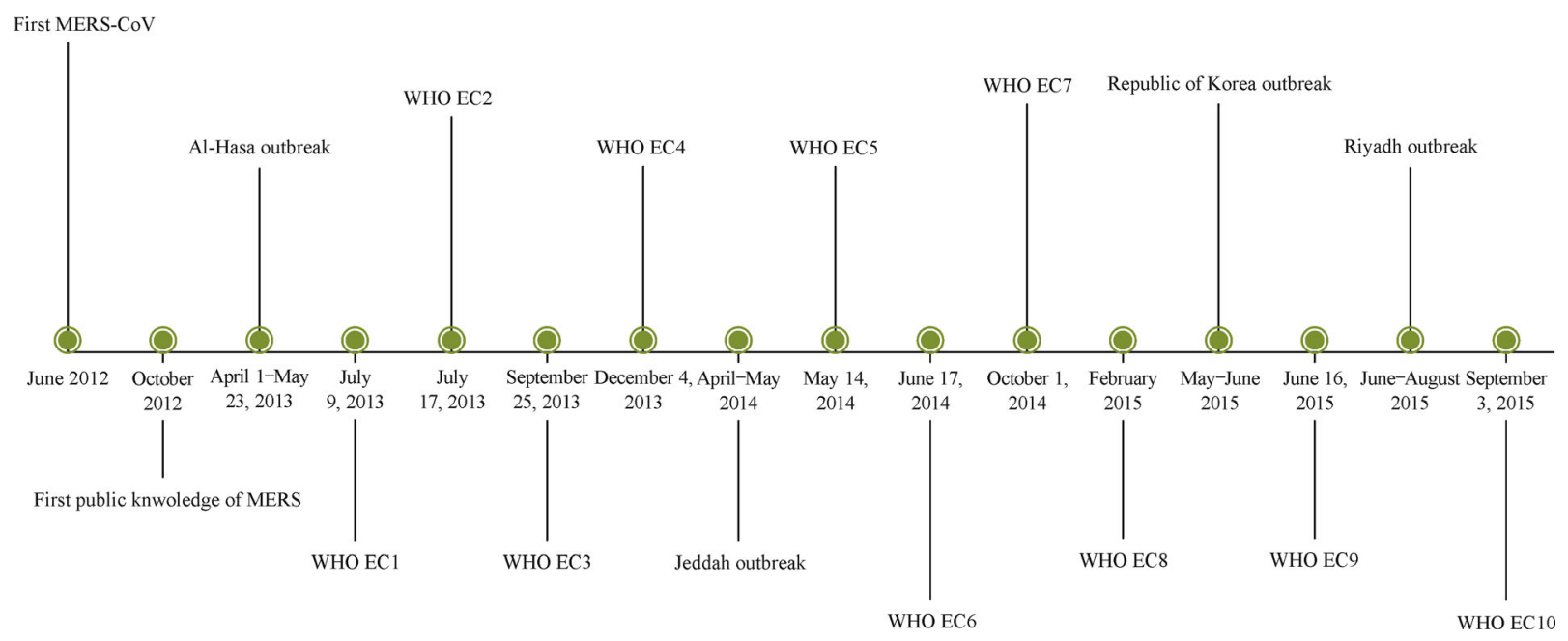

Fig. 2 Timeline of WHO Emergency Committee (EC) meeting to discuss the IHR MERS-COV situation in relation to major events in the time of the disease. 
sequencing success rates. Thus, $\mathrm{Ct}$ values are sufficient predictors of the success that is independent on sample type or source $[24,25]$.

\section{Infection control}

MERS-CoV was found to be stable in the environment. The virus can survive on plastic and steel for up to $48 \mathrm{~h}$ at lower temperatures and humidity; once temperature and humidity increase, the virus becomes less viable [57]. The virus is viable at $20^{\circ} \mathrm{C}$ and $40 \%$ humidity for 48 hours, at $30{ }^{\circ} \mathrm{C}$ and $30 \%$ humidity for 24 hours and at $30{ }^{\circ} \mathrm{C}$ and $80 \%$ humidity for 8 hours only [57]. In another study, increasing the temperature from $25{ }^{\circ} \mathrm{C}$ to $65{ }^{\circ} \mathrm{C}$ adversely affects viral infectivity [58]. The WHO advocates contact and droplet precautions with airborne isolation in hospital settings when dealing with an aerosol-generating procedure [56]; the United States Centers for Disease Control and Prevention (CDC) and the European Centre for Disease Prevention and Control (ECDC) call for airborne infection isolation precautions [59-61].

Multiple hospital outbreaks of MERS-CoV infection in KSA were controlled effectively using infection control precautions recommended by the WHO and the Saudi Ministry of Health $[4,5,26,36]$.

\section{Therapeutic options}

There are no proven therapeutic agents for the treatment of MERS-CoV patients. Existing antiviral agents can be repurposed against MERS-CoV [62,63]. Interferon and ribavirin were suggested to be possible therapeutic options based on the SARS data [63]. These two agents were used to treat five patients with MERS-CoV infection [64]. The median time to therapy was 19 days, and no improvement was observed [64]. Ribavirin and interferon were used in 20 patients with MERS-CoV at a median of three days [65]. The 14-day survival was $70 \%$ (14 of 20 patients) in the treatment group vs. $29 \%$ (7 of 24 of patients) in a historical group $(P=0.004)$ with no survival improvement at 28 days $(30 \%$ vs. $17 \% ; P=0.054)$ [63]. In an observational study, interferon- $\alpha 2 \mathrm{a}$ with ribavirin and interferon- $\beta 1 \mathrm{a}$ with ribavirin showed similar results in treating MERS-CoV [40].

The potential repurposed drugs for MERS therapy include ribavirin with or without interferon, HIV protease inhibitors (lopinavir and nelfinavir), cyclophilin inhibitors (cyclosporin and alisporivir), chloroquine, mycophenolic acid, and nitazoxanide [66]. The use of interferon- $\alpha 2 b$ and ribavirin decreased viral replication in the rhesus macaques model within $8 \mathrm{~h}$ of MERS-CoV infection [67]. In vitro, ribavirin inhibits MERS-CoV; however, the required doses are extremely high to obtain in vivo $[68,69]$.
In vitro, nelfinavir and lopinavir achieved inhibitory concentrations against MERS-CoV [70]. In a primate model, the mortality rate at $36 \mathrm{~h}$ post-inoculation was $67 \%$ in untreated versus $0 \%-33 \%$ in the lopinavir- or ritonavirtreated and interferon- $\beta 1 b$-treated animals [71]; the combination was used in another case [72].

\section{Future directions}

To understand the MERS-CoV disease further, resolving the issues related to the specific host and the specific transmission mode and determining the factors that increase transmission within healthcare environments are crucial. The viral kinetics of MERS-CoV within different body compartments is another aspect that needs further examination. The optimal therapeutic options and strategies to predict the occurrence and severity of the disease require further analysis.

\section{Compliance with ethics guidelines}

Jaffar A. Al-Tawfiq, Ali S. Omrani, and Ziad A. Memish declare that they have no conflict of interest. This manuscript is a review article and does not involve a research protocol requiring approval by the relevant institutional review board or ethics committee.

\section{References}

1. Al-Tawfiq JA, Zumla A, Memish ZA. Travel implications of emerging coronaviruses: SARS and MERS-CoV. Travel Med Infect Dis $2014 ;$ 12(5): 422-428

2. Al-Tawfiq JA, Zumla A, Memish ZA. Coronaviruses: severe acute respiratory syndrome coronavirus and Middle East respiratory syndrome coronavirus in travelers. Curr Opin Infect Dis 2014; 27 (5): 411-417

3. Word Health Organization. Middle East respiratory syndrome coronavirus (MERS-CoV) — Kuwait. Available at: http://www. who.int/csr/don/23-september-2015-mers-kuwait/en/. Last accessed April 5, 2016

4. Drosten C, Muth D, Corman VM, Hussain R, Al Masri M, HajOmar W, Landt O, Assiri A, Eckerle I, Al Shangiti A, Al-Tawfiq JA, Albarrak A, Zumla A, Rambaut A, Memish ZA. An observational, laboratory-based study of outbreaks of middle East respiratory syndrome coronavirus in Jeddah and Riyadh, Kingdom of Saudi Arabia, 2014. Clin Infect Dis 2015; 60(3): 369-377

5. Oboho IK, Tomczyk SM, Al-Asmari AM, Banjar AA, Al-Mugti H, Aloraini MS, Alkhaldi KZ, Almohammadi EL, Alraddadi BM, Gerber SI, Swerdlow DL, Watson JT, Madani TA. 2014 MERS$\mathrm{CoV}$ outbreak in Jeddah - a link to health care facilities. N Engl J Med 2015; 372(9): 846-854

6. WHO. Middle East respiratory syndrome coronavirus (MERS-CoV) — Republic of Korea. Available at: http://www.who.int/csr/don/30may-2015-mers-korea/en/

7. FluTrackers. South Korea Coronavirus MERS Case List —including 
imported and exported cases. Available at: https://flutrackers.com/ forum/forum/novel-coronavirus-ncov-mers-2012-2014/novel-coronavirus-who-chp-wpro-ecdc-oie-fao-moa-reports-and-updates/ south-korea-coronavirus/732065-south-korea-coronavirus-merscase-list-including-imported-and-exported-cases

8. World Health Organization. Middle East respiratory syndrome coronavirus (MERS-CoV): summary and risk assessment of current situation in the Republic of Korea and China — as of 19 June 2015. Available at: http://www.who.int/emergencies/mers-cov/mers-covrepublic-of-korea-and-china-risk-assessment-19-june-2015.pdf?ua $=1$

9. World Health Organization. Middle East respiratory syndrome coronavirus (MERS-CoV): WHO statement on the tenth meeting of the IHR Emergency Committee regarding MERS, 3 September 2015. Available at: http://www.who.int/mediacentre/news/statements/2015/ihr-emergency-committee-mers/en/

10. Wolfe ND, Dunavan CP, Diamond J. Origins of major human infectious diseases. Nature 2007; 447(7142): 279-283

11. The Economic and Social Impact of Emerging Infectious Disease. Mitigation through Detection, Research, and Response. Available at: http://www.healthcare.philips.com/main/shared/assets/documents/ bioshield/ecoandsocialimpactofemerginginfectiousdisease_111208. pdf

12. Memish ZA, Alhakeem R, Stephens GM. Saudi Arabia and the emergence of a novel coronavirus. East Mediterr Health J 2013; 19 (Suppl 1): S7-S11

13. Zaki AM, van Boheemen S, Bestebroer TM, Osterhaus AD, Fouchier RA. Isolation of a novel coronavirus from a man with pneumonia in Saudi Arabia. N Engl J Med 2012; 367(19): 18141820

14. Al-Tawfiq JA, Memish ZA. An update on Middle East respiratory syndrome: 2 years later. Expert Rev Respir Med 2015; 9(3): $327-$ 335

15. Hall AJ, Tokars JI, Badreddine SA, Saad ZB, Furukawa E, Al Masri M, Haynes LM, Gerber SI, Kuhar DT, Miao C, Trivedi SU, Pallansch MA, Hajjeh R, Memish ZA. Health care worker contact with MERS patient, Saudi Arabia. Emerg Infect Dis 2014; 20(12): 2148-2151

16. Memish ZA, Mishra N, Olival KJ, Fagbo SF, Kapoor V, Epstein JH, Alhakeem R, Durosinloun A, Al Asmari M, Islam A, Kapoor A, Briese T, Daszak P, Al Rabeeah AA, Lipkin WI. Middle East respiratory syndrome coronavirus in bats, Saudi Arabia. Emerg Infect Dis 2013; 19(11): 1819-1823

17. Memish ZA, Al-Tawfiq JA, Makhdoom HQ, Al-Rabeeah AA, Assiri A, Alhakeem RF, AlRabiah FA, Al Hajjar S, Albarrak A, Flemban H, Balkhy H, Barry M, Alhassan S, Alsubaie S, Zumla A. Screening for Middle East respiratory syndrome coronavirus infection in hospital patients and their healthcare worker and family contacts: a prospective descriptive study. Clin Microbiol Infect 2014; 20(5): 469-474

18. World Health Organization. Middle East respiratory syndrome coronavirus case definition for reporting to WHO: interim case definition 14 July 2015. http://www.who.int/csr/disease/coronavirus_infections/mers_cov_interim_case_definition_Jul2015.pdf? ua $=1$

19. Al-Tawfiq JA, Memish ZA. Middle East respiratory syndrome coronavirus: epidemiology and disease control measures. Infect
Drug Resist 2014; 7: 281-287

20. Müller MA, Meyer B, Corman VM, Al-Masri M, Turkestani A, Ritz D, Sieberg A, Aldabbagh S, Bosch BJ, Lattwein E, Alhakeem RF, Assiri AM, Albarrak AM, Al-Shangiti AM, Al-Tawfiq JA, Wikramaratna P, Alrabeeah AA, Drosten C, Memish ZA. Presence of Middle East respiratory syndrome coronavirus antibodies in Saudi Arabia: a nationwide, cross-sectional, serological study. Lancet Infect Dis 2015; 15(5): 559-564

21. Memish ZA, Zumla AI, Al-Hakeem RF, Al-Rabeeah AA, Stephens GM. Family cluster of Middle East respiratory syndrome coronavirus infections. N Engl J Med 2013; 368(26): 2487-2494

22. Omrani AS, Matin MA, Haddad Q, Al-Nakhli D, Memish ZA, Albarrak AM. A family cluster of Middle East Respiratory syndrome coronavirus infections related to a likely unrecognized asymptomatic or mild case. Int J Infect Dis 2013; 17(9): e668-e672

23. Memish ZA, Cotten M, Watson SJ, Kellam P, Zumla A, Alhakeem RF, Assiri A, Rabeeah AA, Al-Tawfiq JA. Community case clusters of Middle East respiratory syndrome coronavirus in Hafr Al-Batin, Kingdom of Saudi Arabia: a descriptive genomic study. Int J Infect Dis 2014; 23: 63-68

24. Cotten M, Watson SJ, Zumla AI, Makhdoom HQ, Palser AL, Ong SH, Al Rabeeah AA, Alhakeem RF, Assiri A, Al-Tawfiq JA, Albarrak A, Barry M, Shibl A, Alrabiah FA, Hajjar S, Balkhy HH, Flemban H, Rambaut A, Kellam P, Memish ZA. Spread, circulation, and evolution of the Middle East respiratory syndrome coronavirus. MBio 2014; 5(1): e01062-e13

25. Cotten M, Watson SJ, Kellam P, Al-Rabeeah AA, Makhdoom HQ, Assiri A, Al-Tawfiq JA, Alhakeem RF, Madani H, AlRabiah FA, Al Hajjar S, Al-nassir WN, Albarrak A, Flemban H, Balkhy HH, Alsubaie S, Palser AL, Gall A, Bashford-Rogers R, Rambaut A, Zumla AI, Memish ZA. Transmission and evolution of the Middle East respiratory syndrome coronavirus in Saudi Arabia: a descriptive genomic study. Lancet 2013; 382(9909): 1993-2002

26. Assiri A, McGeer A, Perl TM, Price CS, Al Rabeeah AA, Cummings DA, Alabdullatif ZN, Assad M, Almulhim A, Makhdoom H, Madani H, Alhakeem R, Al-Tawfiq JA, Cotten M, Watson SJ, Kellam P, Zumla AI, Memish ZA; KSA MERS-CoV Investigation Team.Hospital outbreak of Middle East respiratory syndrome coronavirus. N Engl J Med 2013; 369(5): 407-416

27. Memish ZA, Al-Tawfiq JA. Middle East respiratory syndrome coronavirus infection control: the missing piece? Am J Infect Control 2014; 42(12): 1258-1260

28. Al-Tawfiq JA, Memish ZA. Middle East respiratory syndrome coronavirus: transmission and phylogenetic evolution. Trends Microbiol 2014; 22(10): 573-579

29. Hijawi B, Abdallat M, Sayaydeh A, Alqasrawi S, Haddadin A, Jaarour N, Alsheikh S, Alsanouri T. Novel coronavirus infections in Jordan, April 2012: epidemiological findings from a retrospective investigation. East Mediterr Health J 2013; 19(Suppl 1): S12-S18

30. Al-Abdallat MM, Payne DC, Alqasrawi S, Rha B, Tohme RA, Abedi GR, Al Nsour M, Iblan I, Jarour N, Farag NH, Haddadin A, Al-Sanouri T, Tamin A, Harcourt JL, Kuhar DT, Swerdlow DL, Erdman DD, Pallansch MA, Haynes LM, Gerber SI, Sabri N, Al Azhari M, Khazali H, Al Maayah M, Bilbeisi A, Dawood N, Al Zubi B, Meflih J, Mounds T, Fitzner J, Eltom A, Mafi A, Miao C, Caidi H, Trivedi S, Kamili S, Hall AJ, Curns A, Moore J, Pham H, Zimmerman C, Farnon E, Giorgi G, Gerber R; Jordan MERS-CoV 
Investigation Team. Hospital-associated outbreak of Middle East respiratory syndrome coronavirus: a serologic, epidemiologic, and clinical description. Clin Infect Dis 2014; 59(9): 1225-1233

31. MERS-Coronavirus Molecular Epidemiology and Genetic Analysis - Origin and Evolution. Available at: http://epidemic.bio.ed. ac.uk/coronavirus_analysis (Submitted by Andrew Rambaut on Fri, 2013-06-14 10:26)

32. Lau SK, Li KS, Tsang AK, Lam CS, Ahmed S, Chen H, Chan KH, Woo PC, Yuen KY. Genetic characterization of Betacoronavirus lineage $\mathrm{C}$ viruses in bats reveals marked sequence divergence in the spike protein of pipistrellus bat coronavirus HKU5 in Japanese pipistrelle: implications for the origin of the novel Middle East respiratory syndrome coronavirus. J Virol 2013; 87(15): 86388650

33. World Health Organization. Middle East respiratory syndrome coronavirus (MERS-CoV) summary and literature update as of 9 May 2014. Available at: www.who.int/csr/disease/coronavirus_infections/MERS_CoV_Update_09_May_2014.pdf?ua = 1

34. World health organization. Middle East respiratory syndrome coronavirus (MERS-CoV). MERS-CoV in Republic of Korea at a glance. Available at: http://www.who.int/csr/don/21-july-2015mers-korea/en/

35. Cowling BJ, Park M, Fang VJ, Wu P, Leung GM, Wu JT. Preliminary epidemiological assessment of MERS-CoV outbreak in South Korea, May to June 2015. Euro Surveill 2015; 20(25): 7-13 Available at: http://www.eurosurveillance.org/ViewArticle.aspx? ArticleId $=21163$

36. Saad M, Omrani AS, Baig K, Bahloul A, Elzein F, Matin MA, Selim MA, Al Mutairi M, Al Nakhli D, Al Aidaroos AY, Al Sherbeeni N, Al-Khashan HI, Memish ZA, Albarrak AM. Clinical aspects and outcomes of 70 patients with Middle East respiratory syndrome coronavirus infection: a single-center experience in Saudi Arabia. Int J Infect Dis 2014; 29: 301-306

37. Al-Tawfiq JA, Hinedi K, Ghandour J, Khairalla H, Musleh S, Ujayli A, Memish ZA. Middle East respiratory syndrome coronavirus: a case-control study of hospitalized patients. Clin Infect Dis 2014; 59 (2): 160-165

38. Arabi YM, Arifi AA, Balkhy HH, Najm H, Aldawood AS, Ghabashi A, Hawa H, Alothman A, Khaldi A, Al Raiy B. Clinical course and outcomes of critically ill patients with Middle East respiratory syndrome coronavirus infection. Ann Intern Med 2014; 160(6): 389-397

39. Assiri A, Al-Tawfiq JA, Al-Rabeeah AA, Al-Rabiah FA, Al-Hajjar S, Al-Barrak A, Flemban H, Al-Nassir WN, Balkhy HH, AlHakeem RF, Makhdoom HQ, Zumla AI, Memish ZA. Epidemiological, demographic, and clinical characteristics of 47 cases of Middle East respiratory syndrome coronavirus disease from Saudi Arabia: a descriptive study. Lancet Infect Dis 2013; 13(9): 752761

40. Shalhoub S, Farahat F, Al-Jiffri A, Simhairi R, Shamma O, Siddiqi N, Mushtaq A. IFN- $\alpha 2$ a or IFN- $\beta 1$ a in combination with ribavirin to treat Middle East respiratory syndrome coronavirus pneumonia: a retrospective study. J Antimicrob Chemother 2015; 70(7): 2129 2132

41. Who Mers-Cov Research Group. State of Knowledge and Data Gaps of Middle East Respiratory Syndrome Coronavirus (MERSCoV) in Humans. PLoS Curr 2013 Nov 12; 5. pii: ecurrents. outbreaks.0bf719e352e7478f8ad85fa30127ddb8

42. World Health Organization. Middle East respiratory syndrome coronavirus (MERS-CoV) summary and literature update-as of 20 January 2014. Available at: http://www.who.int/csr/disease/coronavirus_infections/MERS_CoV_Update_20_Jan_2014.pdf

43. Memish ZA, Al-Tawfiq JA, Makhdoom HQ, Assiri A, Alhakeem RF, Albarrak A, Alsubaie S, Al-Rabeeah AA, Hajomar WH, Hussain R, Kheyami AM, Almutairi A, Azhar EI, Drosten C, Watson SJ, Kellam P, Cotten M, Zumla A. Respiratory tract samples, viral load, and genome fraction yield in patients with Middle East respiratory syndrome. J Infect Dis 2014; 210(10): 1590-1594

44. World Health Organization. Revised case definition for reporting to WHO - Middle East respiratory syndrome coronavirus. Available at: http://ecdc.europa.eu/en/publications/Publications/MERS-CoVrapid-risk-assessment-August-2015.pdf

45. European CDC. Severe respiratory disease associated with Middle East respiratory syndrome coronavirus (MERS-CoV) $21^{\text {st }}$ update, 21 October 2015. Available at: http://ecdc.europa.eu/en/publications/Publications/MERS-CoV-rapid-risk-assessment-october2015.pdf

46. World Health Organization. IHR Emergency Committee concerning Middle East respiratory syndrome coronavirus. Available at: http:// www.who.int/ihr/ihr_ec_2013/en/

47. World Health Organization. Report on Sep 2, 2015 meeting: http:// www.who.int/entity/mediacentre/news/statements/2015/ihr-emergency-committee-mers/en/index.html

48. Soliman T, Cook AR, Coker RJ. Pilgrims and MERS-CoV: what's the risk? Emerg Themes Epidemiol 2015; 12(1): 3

49. Lessler J, Rodriguez-Barraquer I, Cummings DA, Garske T, Van Kerkhove M, Mills H, Truelove S, Hakeem R, Albarrak A, Ferguson NM; MERS-CoV Scenario Modeling Working Group. Estimating Potential Incidence of MERS-CoV Associated with Hajj Pilgrims to Saudi Arabia, 2014. PLoS Curr 2014 Nov 24; 6. pii: ecurrents. outbreaks.c5c9c9abd636164a9b6fd4dbda974369

50. Sridhar S, Brouqui P, Parola P, Gautret P. Imported cases of Middle East respiratory syndrome: an update. Travel Med Infect Dis 2015; 13(1): 106-109

51. Zumla A, Mwaba P, Bates M, Al-Tawfiq JA, Maeurer M, Memish ZA. The Hajj pilgrimage and surveillance for Middle East Respiratory syndrome coronavirus in pilgrims from African countries. Trop Med Int Health 2014; 19(7): 838-840

52. Annan A, Owusu M, Marfo KS, Larbi R, Sarpong FN, AduSarkodie Y, Amankwa J, Fiafemetsi S, Drosten C, Owusu-Dabo E, Eckerle I. High prevalence of common respiratory viruses and no evidence of Middle East respiratory syndrome coronavirus in Hajj pilgrims returning to Ghana, 2013. Trop Med Int Health 2015; 20 (6): 807-812

53. Gautret P, Charrel R, Benkouiten S, Belhouchat K, Nougairede A, Drali T, Salez N, Memish ZA, Al Masri M, Lagier JC, Million M, Raoult D, Brouqui P, Parola P. Lack of MERS coronavirus but prevalence of influenza virus in French pilgrims after 2013 Hajj. Emerg Infect Dis 2014; 20(4): 728-730

54. Memish ZA, Assiri A, Almasri M, Alhakeem RF, Turkestani A, Al Rabeeah AA, Al-Tawfiq JA, Alzahrani A, Azhar E, Makhdoom HQ, Hajomar WH, Al-Shangiti AM, Yezli S. Prevalence of MERS-CoV nasal carriage and compliance with the Saudi health recommenda- 
tions among pilgrims attending the 2013 Hajj. J Infect Dis 2014; 210 (7): 1067-1072

55. Gierer S, Hofmann-Winkler H, Albuali WH, Bertram S, Al-Rubaish AM, Yousef AA, Al-Nafaie AN, Al-Ali AK, Obeid OE, Alkharsah KR, Pöhlmann S. Lack of MERS coronavirus neutralizing antibodies in humans, eastern province, Saudi Arabia. Emerg Infect Dis 2013; 19(12): 2034-2036

56. Drosten C, Meyer B, Müller MA, Corman VM, Al-Masri M, Hossain R, Madani H, Sieberg A, Bosch BJ, Lattwein E, Alhakeem RF, Assiri AM, Hajomar W, Albarrak AM, Al-Tawfiq JA, Zumla AI, Memish ZA. Transmission of MERS-coronavirus in household contacts. N Engl J Med 2014; 371(9): 828-835

57. van Doremalen N, Bushmaker T, Munster VJ. Stability of Middle East respiratory syndrome coronavirus (MERS-CoV) under different environmental conditions. Euro Surveill 2013; 18(38): 20590

58. Leclercq I, Batéjat C, Burguière AM, Manuguerra JC. Heat inactivation of the Middle East respiratory syndrome coronavirus. Influenza Other Respi Viruses 2014; 8(5): 585-586

59. WHO. Infection prevention and control of epidemic-and pandemic prone acute respiratory infections in health care. Available at: http:// www.who.int/csr/bioriskreduction/infection_control/publication/en/

60. ECDC. Available at: www.ecdc.europa.eu/en/press/news/_lay-outs/ forms/News_DispForm.aspx ? List $=8 \mathrm{db} 7286 \mathrm{c}-\mathrm{fe} 2 \mathrm{~d}-476 \mathrm{c}-9133$ $18 \mathrm{ff} 4 \mathrm{cb} 1 \mathrm{~b} 568 \& \mathrm{ID}=1002$

61. CDC. Interim infection prevention and control recommendations for hospitalized patients with Middle East respiratory syndrome coronavirus. MERSCoV 15 May 2014. Available at: www.cdc. gov/coronavirus/mers/infectionpreventioncontrol.html\#infectionprevention

62. Coleman CM, Frieman MB. Treating MERS-CoV during an outbreak. Lancet Infect Dis 2014; 14(11): 1030-1031

63. Momattin H, Mohammed K, Zumla A, Memish ZA, Al-Tawfiq JA. Therapeutic options for Middle East respiratory syndrome coronavirus (MERS-CoV) - possible lessons from a systematic review of SARS-CoV therapy. Int J Infect Dis 2013; 17(10): e792-e798

64. Al-Tawfiq JA, Momattin H, Dib J, Memish ZA. Ribavirin and interferon therapy in patients infected with the Middle East respiratory syndrome coronavirus: an observational study. Int J Infect Dis 2014; 20: 42-46

65. Omrani AS, Saad MM, Baig K, Bahloul A, Abdul-Matin M, Alaidaroos AY, Almakhlafi GA, Albarrak MM, Memish ZA, Albarrak AM. Ribavirin and interferon $\alpha$-2a for severe Middle East respiratory syndrome coronavirus infection: a retrospective cohort study. Lancet Infect Dis 2014; 14(11): 1090-1095

66. Zumla A, Memish ZA, Maeurer M, Bates M, Mwaba P, Al-Tawfiq JA, Denning DW, Hayden FG, Hui DS. Emerging novel and antimicrobial-resistant respiratory tract infections: new drug development and therapeutic options. Lancet Infect Dis 2014; 14(11): 1136-1149

67. Falzarano D, de Wit E, Rasmussen AL, Feldmann F, Okumura A, Scott DP, Brining D, Bushmaker T, Martellaro C, Baseler L, Benecke AG, Katze MG, Munster VJ, Feldmann H. Treatment with interferon- $\alpha 2 b$ and ribavirin improves outcome in MERS-CoVinfected rhesus macaques. Nat Med 2013; 19(10): 1313-1317

68. Chan JF, Chan KH, Kao RY, To KK, Zheng BJ, Li CP, Li PT, Dai J, Mok FK, Chen H, Hayden FG, Yuen KY. Broad-spectrum antivirals for the emerging Middle East respiratory syndrome coronavirus. J Infect 2013; 67(6): 606-616

69. Falzarano D, de Wit E, Martellaro C, Callison J, Munster VJ, Feldmann H. Inhibition of novel coronavirus replication by a combination of interferon- $\alpha 2 b$ and ribavirin. Sci Rep 2013; 3: 1686

70. Chan JF, Chan KH, Kao RY, To KK, Zheng BJ, Li CP, Li PT, Dai J, Mok FK, Chen H, Hayden FG, Yuen KY. Broad-spectrum antivirals for the emerging Middle East respiratory syndrome coronavirus. J Infect 2013; 67(6): 606-616

71. Chan JF, Yao Y, Yeung ML, Deng W, Bao L, Jia L, Li F, Xiao C, Gao H, Yu P, Cai JP, Chu H, Zhou J, Chen H, Qin C, Yuen KY. Treatment with lopinavir/ritonavir or interferon- $\beta 1 \mathrm{~b}$ improves outcome of MERS-CoV infection in a nonhuman primate model of common marmoset. J Infect Dis 2015; 212(12): 1904-1913

72. Kim UJ, Won EJ, Kee SJ, Jung SI, Jang HC. Combination therapy with lopinavir/ritonavir, ribavirin and interferon- $\alpha$ for Middle East respiratory syndrome: a case report. Antivir Ther 2015 Oct 22. [Epub ahead of print] doi: 10.3851/IMP3002 